\title{
Impact of Herbicides on Yield Attributes and Yields of Blackgram (Vigna mungo L.) and their Residual Effects on Succeeding Crops
}

\author{
R. G. Machhar*, R. V. Hajari, A. K. Mahida, G. D. Hadiya and C. B. Damor \\ Agricultural Research Station, Anand Agricultural University, \\ Derol- 389 320, Dist. Panchmahal, Gujarat, India \\ *Corresponding author
}

\begin{tabular}{l} 
Ke y w o r d s \\
$\begin{array}{l}\text { Herbicides, } \\
\text { Residual effect, } \\
\text { Succeeding crop, } \\
\text { Blackgram }\end{array}$ \\
\hline Article Info \\
$\begin{array}{l}\text { Accepted: } \\
\text { xx May } 2020 \\
\text { Available Online: } \\
\text { xx June } 2020\end{array}$ \\
\hline
\end{tabular}

\section{A B S T R A C T}

A field experiment was conducted at Agricultural Research Station, Anand Agricultural University, Derol, Dist. Panchmahal, Gujarat during Kharif, 2016-17, 2017-18 and 2018-19 to study the impact of herbicides on yield attributes and yield of blackgram (Vigna mungo L.) and their residual effects on succeeding crops. Eight treatments for weed management were studied in randomized block design with four replicatioins. Among the different weed management practices, post-emergence (20 - 25 DAS) application of propaquizalafop $10 \%$ EC $75 \mathrm{~g}$ a.i./ha $\mathrm{fb}$ IC $+\mathrm{HW}$ at $30 \mathrm{DAS}$ proved their superiority followed by quizalofop-ethyl $5 \%$ EC $50 \mathrm{~g}$ a.i./ha $f b$ IC + HW at 30 DAS or fenoxaprop-p-ethyl 9\% EC $67.5 \mathrm{~g}$ a.i./ha $f b$ IC + HW at 30 DAS with respect to recording maximum number of branches/plant, number of pods/plant, number of seeds/pod, seed yield, haulm yield, net return and BCR of blackgram. There was no any residual effect of applied herbicides on succeeding crops viz., maize, gram and wheat was observed during the course of investigation.

\section{Introduction}

Blackgram [Vigna mungo (L.) Heppler] is one of the most important pulse crop grown throughout the country during kharif season. It contributes about 13 per cent of total pulse area and 10 per cent of their total production in our country. In India, blackgram is cultivated in area of 52.79 lakh hectare with the production of 34.92 lakh tonne and productivity of $662 \mathrm{~kg} / \mathrm{ha}$ (Anonymous, 201718). It is extensively grown in the states of Madhya Pradesh, Maharashtra, Andhra Pradesh, Tamil Nadu, Karnataka and Uttar Pradesh. The crop can be grown on all types of soils ranging from sandy loam to heavy clay except the alkaline and saline soil. In Gujarat, blackgram is cultivated in area of 1.36 lakh hectare, while its production is 0.87 lakh tonne and productivity is $636 \mathrm{~kg} / \mathrm{ha}$ 
(Anonymous, 2017-18). The lower productivity of blackgram is mainly due to weed infestation during early stages of crop growth ends up in yield reduction up to 43.2$64.1 \%$ in blackgram (Rathi et al., 2004). An initial period of crop-weed completion of 2040 days is very critical (Saraswat and Mishra, 1993). Weed emergence in blackgram being almost with the crop emergence leading to crop-weed competition from initial stages and reduce yields to the extent of $78 \%$ and sometimes lead to the total failure of crop (Gogoi et al., 1992). Therefore, removal of weeds at appropriate time using a suitable weed control practices is essential to obtain high yields of blackgram. In blackgram, weeds could be controlled by hand weeding (Chand et al., 2004). However, hand weeding is laborious, time consuming, costly and tedious. Moreover, many times labour is not available at the critical period of weed removal. Furthermore, weather conditions do not permit timely hand weeding due to wet field conditions. Use of herbicides offers an alternative for possible effective control of weeds. Therefore, the present study was conducted to study the impacts of herbicides on yield attributes and yield of blackgram (Vigna mungo L.) and their residual effects on succeeding crops in middle Gujarat condition.

\section{Materials and Methods}

The field experiment was conducted at Agricultural Research Station, Anand Agricultural University, Derol, Panchmahal (Gujarat) during Kharif season of the year 2016-17, 2017-18 and 2018-19. The soil of the experimental field was loamy sand in texture having low in available nitrogen and medium in available phosphorus and high in potassium with $\mathrm{pH}$ 8.2. The experiment was laid out in randomized block design with four replications. Eight treatment comprised viz., pendimethalin 30\% EC $1000 \mathrm{~g}$ a.i./ha PE $f b$ $\mathrm{IC}+\mathrm{HW}$ at $30 \mathrm{DAS}\left(\mathrm{T}_{1}\right)$, pendimethalin $30 \%$
EC $1000 \mathrm{~g}$ a.i./ha PE $f b$ quizalofop-ethyl 5\% EC $50 \mathrm{~g}$ a.i./ha PoE $\left(\mathrm{T}_{2}\right)$, quizalofop-ethyl 5\% EC $50 \mathrm{~g}$ a.i./ha PoE $f b$ IC + HW at 30 DAS $\left(\mathrm{T}_{3}\right)$, imazamox $35 \%$ + imazethapyr $35 \%$ (Pre-mix) WG 70 g a.i./ha PoE $\left(\mathrm{T}_{4}\right)$, propaquizafop 10\% EC $75 \mathrm{~g}$ a.i./ha PoE $f b$ IC $+\mathrm{HW}$ at $30 \mathrm{DAS}\left(\mathrm{T}_{5}\right)$, fenoxaprop-p-ethyl 9\% EC $67.5 \mathrm{~g}$ a.i./ha PoE $f b$ IC $+\mathrm{HW}$ at 30 DAS ( $\mathrm{T}_{6}$ ), FP (IC $f b \mathrm{HW}$ at $20 \& 40$ DAS) $\left(\mathrm{T}_{7}\right)$ and weedy check $\left(\mathrm{T}_{8}\right)$. The herbicides were applied by using knapsack sprayer fitted with flat fan nozzle by mixing in 500 litre of water/ha as per treatments. Blackgram cv. T 9 was sown manually keeping the distance of $30 \mathrm{~cm}$ between two rows in all the three years of experimentation. The plot size was $3.60 \mathrm{x}$ $5.00 \mathrm{~m}$. All the recommended package of practices was adopted to raise the crop. The recommended dose of NPK and plant protection measures was followed as per general recommendations. The seed and haulm yield was recorded from the net plot prevailing market price on the basis of pooled yield data and benefit cost ratio were calculated. After harvest the blackgram crop succeeding crops was sown without disturbing the layout. In succeeding crop of winter season three row sown of maize and gram where as four row of wheat were sown in each plot. The data on plant stand, plant height and dry matter accumulation by succeeding crop were recorded at 30 days after sowing.

\section{Results and Discussion}

\section{Effect of growth and yield attributes}

Plant stand was not affected significantly by different weed control practices (Table 1). Plant height was recorded significantly higher at harvest $(49.7 \mathrm{~cm})$ under application of propaquizafop 10\% EC $75 \mathrm{~g}$ a.i./ha PoE $f b$ IC $+\mathrm{HW}$ at 30 DAS but it was at par with majority all the treatment except weedy check (Table 1). Among different herbicidal 
application, more number of branches (4.0 branches/plant) was noticed under application of propaquizafop $10 \%$ EC $75 \mathrm{~g}$ a.i./ha PoE $f b$ $\mathrm{IC}+\mathrm{HW}$ at 30 DAS but it was at par with $\mathrm{T}_{3}$, $\mathrm{T}_{4}$ and $\mathrm{T}_{2}$ (Table 1). Further, it was observed that number of pods/plant (46.3 pods/plant) was recorded maximum under application of quizalofop-ethyl 5\% EC $50 \mathrm{~g}$ a.i./ha $f b$ IC + HW at 30 DAS but it remain at par with almost all the herbicidal treatment except treatments $\mathrm{T}_{4}$ and $\mathrm{T}_{8}$.

The number of seeds/pod at harvest was recorded significantly higher (26.9 seeds/pod) under application of propaquizafop $10 \% \mathrm{EC}$ $75 \mathrm{~g}$ a.i./ha PoE $f b \mathrm{IC}+\mathrm{HW}$ at $30 \mathrm{DAS}$ as compared to rest of the treatment except treatments $\mathrm{T}_{1}, \mathrm{~T}_{7}, \mathrm{~T}_{3}, \mathrm{~T}_{2}, \mathrm{~T}_{6}, \mathrm{~T}_{4}$. The lowest seeds/pod was recorded under weedy check (21.7/pod). The data on pod length was not affected significantly by different weed control practices. Mundra and Maliwal (2012) also reported that application of quizalofopethyl $50 \mathrm{~g} / \mathrm{ha}$ recorded maximum number of branches/plant, number of pods/plant and number of seeds/pod. The increase in growth and yield attributes might be due to the reduction in weed competitiveness due to effective control of weeds which ultimately favored better environment for growth and development of crop. Present finding also conformity with Balyan et al. (2016).

\section{Seed and haulm yield}

Seed and haulm yield of the crop was distinctly influenced by the weed management treatments. Maximum seed yield (910 kg/ha) and haulm yield (1309 kg/ha) was obtained under application of propaquizafop $10 \%$ EC $75 \mathrm{~g}$ a.i./ha PoE fb IC + HW at 30 DAS as compared to rest of the treatment except application of quizalofop-ethyl 5\% EC $50 \mathrm{~g}$ a.i./ha PoE. Whereas, significantly the lowest seed yield (454 kg/ha) and haulm yield $(656 \mathrm{~kg} / \mathrm{ha})$ was recorded under weedy check (Table 2). Jana et al., (2012) also reported the application of propaquizafop 10\% EC @62.5 $\mathrm{g}$ a. i ha ${ }^{-1}$ also proved higher productivity.

\section{Economics}

The economics analysis of the different weed management practices for the balckgram indicated that post emergence application of propaquizafop $75 \mathrm{~g} / \mathrm{ha} \mathrm{PoE}$ at 20 to $25 \mathrm{DAS}$ $f b \quad \mathrm{IC}+\mathrm{HW}$ at 30 DAS recorded highest BCR of 1.90 along with maximum net return (Rs. 25753/ha) and was closely followed by application of quizalofop-ethyl $50 \mathrm{~g} / \mathrm{ha} \mathrm{PoE}$ at 20 to 25 DAS $f b$ IC + HW at 30 DAS which recorded $\mathrm{BCR}$ of 1.70 with net return of Rs.20527/ha and fenoxaprop-p-ethyl 67.5 $\mathrm{g} / \mathrm{ha} \mathrm{PoE}$ at 20 to $25 \mathrm{DAS} f b \mathrm{IC}+\mathrm{HW}$ at 30 DAS which recorded BCR of 1.73 with net return of Rs. 21022/ha (Table 2). The weedy check treatment had the lowest BCR of 1.36 with net return of Rs. 7170/ha due to poor yield in this treatment. The results confirm the findings of Mundra and Maliwal (2012).

\section{Residual effect of herbicides applied to blackgram on succeeding rabi crops}

The result indicated that herbicides applied to blackgram did not show any significant effect on plant stand, plant height and dry matter accumulation of all the succeeding crops viz., maize, gram and wheat (Table 3). From the results, it was clearly indicated that all the applied herbicides is safe for using in succeeding crop grown in rotation with blackgram. Yadav and Bhullar (2014) reported that application of pendimethali, imazatyper + imazamox and quizalfop on blackgram crop did not show any residual effect on succeeding crop of wheat. Jana et al (2012) reported that application propaquizafop was safer for onion blackgram crop sequence. 
Table.1 Growth and yield attributes of blackgram as influenced by weed management practices (Mean of three years)

\begin{tabular}{|c|c|c|c|c|c|c|c|c|}
\hline \multirow[t]{2}{*}{$\begin{array}{l}\text { Sr. } \\
\text { No. }\end{array}$} & \multirow[t]{2}{*}{ Treatment } & \multicolumn{2}{|c|}{$\begin{array}{c}\text { Plant stand (No./m row } \\
\text { length) }\end{array}$} & \multirow{2}{*}{$\begin{array}{c}\text { Plant } \\
\text { height }(\mathrm{cm}) \\
\text { at harvest }\end{array}$} & \multirow{2}{*}{$\begin{array}{c}\text { No. of } \\
\text { branches/ } \\
\text { plant }\end{array}$} & \multirow{2}{*}{$\begin{array}{l}\text { No. of } \\
\text { pods } \\
\text { /plant }\end{array}$} & \multirow{2}{*}{$\begin{array}{c}\text { No. of } \\
\text { seeds/ } \\
\text { pod }\end{array}$} & \multirow{2}{*}{$\begin{array}{c}\text { Pod } \\
\text { length } \\
(\mathrm{cm})\end{array}$} \\
\hline & & 20 DAS & At harvest & & & & & \\
\hline $\mathbf{T}_{1}$ & $\begin{array}{l}\text { Pendimethalin } 30 \% \text { EC } 1000 \mathrm{~g} \text { a.i./ha PE } f b \text { IC } \\
+\mathrm{HW} \text { at } 30 \mathrm{DAS}\end{array}$ & 13.8 & 11.8 & $46.8^{\mathrm{ab}}$ & $3.7^{\mathrm{bc}}$ & $45.5^{\mathrm{a}}$ & $5.3^{\mathrm{ab}}$ & 4.6 \\
\hline $\mathbf{T}_{2}$ & $\begin{array}{l}\text { Pendimethalin } 30 \% \text { EC } 1000 \mathrm{~g} \text { a.i./ha PE } f b \\
\text { quizalofop-ethyl 5\% EC } 50 \mathrm{~g} \text { a.i./ha PoE }\end{array}$ & 14.2 & 11.9 & $48.0^{\mathrm{ab}}$ & $3.9^{\mathrm{abc}}$ & $45.5^{\mathrm{a}}$ & $5.2^{\mathrm{ab}}$ & 4.5 \\
\hline $\mathbf{T}_{\mathbf{3}}$ & $\begin{array}{l}\text { Quizalofop-ethyl } 5 \% \text { EC } 50 \mathrm{~g} \text { a.i./ha PoE } f b \text { IC } \\
+\mathrm{HW} \text { at } 30 \text { DAS }\end{array}$ & 14.7 & 12.8 & $48.6^{\mathrm{a}}$ & $4.0^{\mathrm{ab}}$ & $46.3^{\mathrm{a}}$ & $5.2^{\mathrm{ab}}$ & 4.6 \\
\hline $\mathbf{T}_{4}$ & $\begin{array}{l}\text { Imazamox } 35 \%+\text { imazethapyr } 35 \% \text { (Pre-mix) } \\
\text { WG } 70 \mathrm{~g} \text { a.i./ha PoE }\end{array}$ & 13.9 & 12.0 & $45.3^{b}$ & $3.9^{\mathrm{abc}}$ & $40.6^{b}$ & $5.1^{\mathrm{ab}}$ & 4.5 \\
\hline $\mathbf{T}_{5}$ & $\begin{array}{l}\text { Propaquizafop } 10 \% \text { EC } 75 \text { g a.i./ha PoE } f b \text { IC } \\
+ \text { HW at } 30 \text { DAS }\end{array}$ & 14.8 & 12.7 & $49.7^{\mathrm{a}}$ & $4.0^{\mathrm{a}}$ & $45.7^{\mathrm{a}}$ & $5.4^{\mathrm{a}}$ & 4.6 \\
\hline $\mathbf{T}_{6}$ & $\begin{array}{l}\text { Fenoxaprop-p-ethyl } 9 \% \text { EC } 67.5 \text { g a.i./ha PoE } \\
f b \text { IC + HW at } 30 \text { DAS }\end{array}$ & 14.4 & 11.8 & $47.6^{\mathrm{ab}}$ & $3.6^{\mathrm{c}}$ & $42.7^{\mathrm{ab}}$ & $5.0^{b}$ & 4.5 \\
\hline $\mathbf{T}_{7}$ & $\mathrm{FP}(\mathrm{IC} f b \mathrm{HW}$ at $20 \& 40 \mathrm{DAS})$ & 14.7 & 12.5 & $49.8^{\mathrm{a}}$ & $4.1^{\mathrm{a}}$ & $43.8^{\mathrm{ab}}$ & $5.3^{\mathrm{ab}}$ & 4.5 \\
\hline \multirow[t]{5}{*}{$\mathbf{T}_{8}$} & Weedy check & 13.6 & 11.5 & $42.3^{c}$ & $2.9^{d}$ & $27.3^{c}$ & $4.3^{\mathrm{c}}$ & 4.5 \\
\hline & S. Em. \pm & 0.34 & 0.34 & 0.34 & 0.95 & 1.37 & 0.09 & 0.06 \\
\hline & F - test & NS & NS & NS & Sig. & Sig. & Sig. & NS \\
\hline & $\mathbf{Y} \times \mathbf{T}$ & $\begin{array}{l}0.61 \\
\mathrm{NS}\end{array}$ & $\begin{array}{l}0.58 \\
\mathrm{NS}\end{array}$ & $\begin{array}{l}1.78 \\
\text { NS }\end{array}$ & $\begin{array}{l}1.78 \\
\text { NS }\end{array}$ & $\begin{array}{l}2.26 \\
\mathrm{NS}\end{array}$ & $\begin{array}{l}0.15 \\
\mathrm{NS}\end{array}$ & $\begin{array}{l}\text { 0.10 } \\
\text { NS }\end{array}$ \\
\hline & CV \% & 8.6 & 9.6 & 7.5 & 7.5 & 10.7 & 5.9 & 4.5 \\
\hline
\end{tabular}

Note:Treatment means with the letter/ letters in common are not significant by Duncan's New Multiple Rang Test at $5 \%$ level of significance 
Table.2 Yield and economics of blackgram as influenced by different weed management practices (Mean of three years)

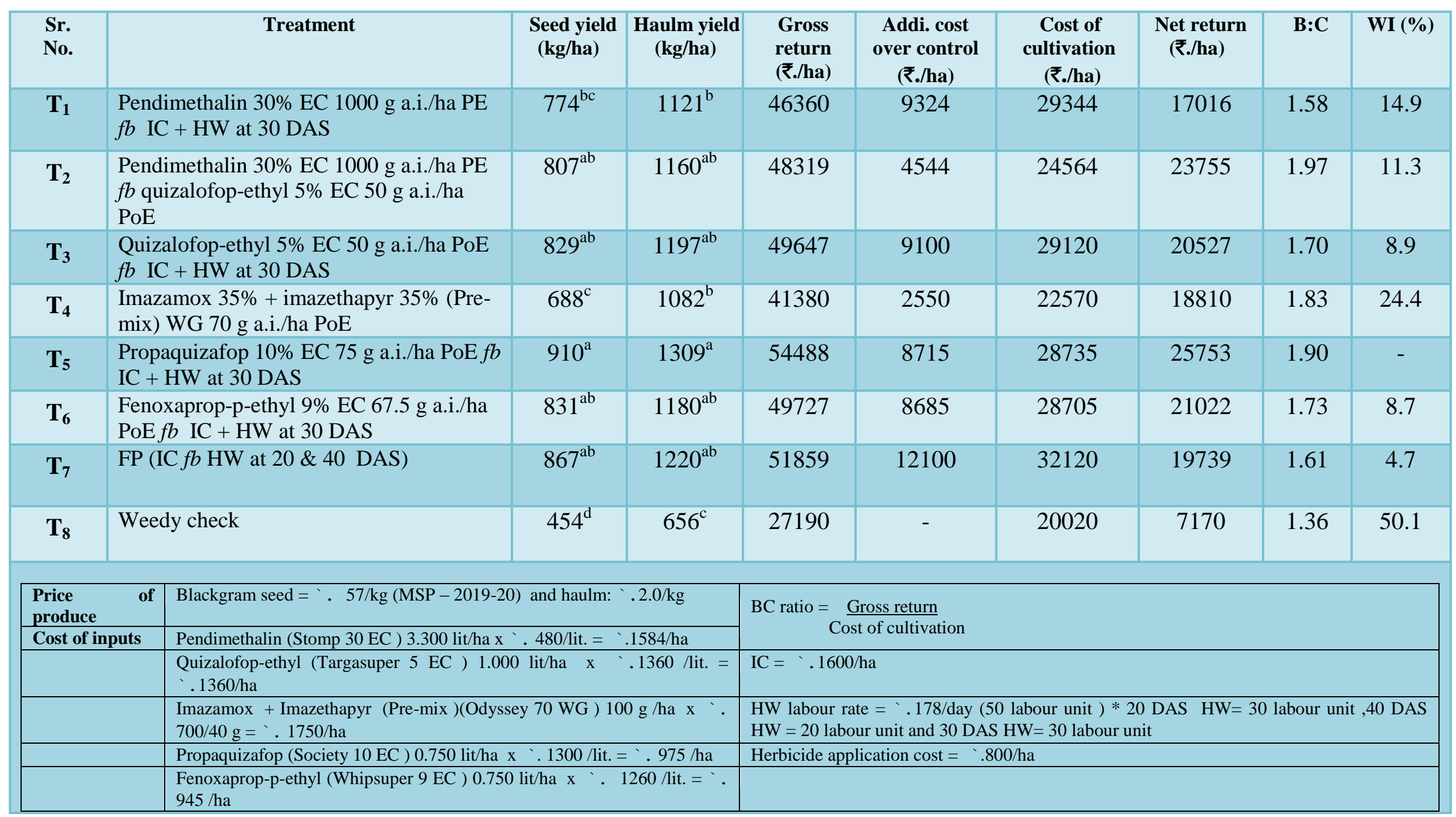

Note: Treatment means with the letter/ letters in common are not significant by Duncan's New Multiple Rang Test at $5 \%$ level of significance. 
Table.3 Succeeding crops as influenced by herbicides applied in blackgram crop (Mean of three years)

\begin{tabular}{|c|c|c|c|c|c|c|c|c|c|c|}
\hline \multirow[t]{2}{*}{$\begin{array}{l}\text { Sr. } \\
\text { No. }\end{array}$} & \multirow[t]{2}{*}{ Treatment } & \multicolumn{3}{|c|}{ Plant stand 15 DAS (No./m row) } & \multicolumn{3}{|c|}{ Plant height $(\mathrm{cm})$ at 30 DAS } & \multicolumn{3}{|c|}{$\begin{array}{c}\text { Dry matter } \\
\text { accumulation (g/plant) } \\
\text { at } 30 \text { DAS }\end{array}$} \\
\hline & & Maize & Gram & Wheat & Maize & Gram & Wheat & Maize & Gram & $\begin{array}{c}\text { Whea } \\
\text { t }\end{array}$ \\
\hline $\mathbf{T}_{1}$ & $\begin{array}{l}\text { Pendimethalin } 30 \% \text { EC } 1000 \mathrm{~g} \text { a.i./ha PE } \\
f b \text { IC }+\mathrm{HW} \text { at } 30 \mathrm{DAS}\end{array}$ & 4.71 & 9.21 & 25.05 & 102.7 & 18.3 & 47.3 & 1.42 & 0.53 & $\mathbf{0 . 7 0}$ \\
\hline $\mathbf{T}_{2}$ & $\begin{array}{l}\text { Pendimethalin } 30 \% \text { EC } 1000 \mathrm{~g} \text { a.i./ha PE } \\
f b \text { quizalofop-ethyl } 5 \% \text { EC } 50 \mathrm{~g} \text { a.i./ha } \\
\text { PoE }\end{array}$ & 4.70 & 9.16 & 26.63 & 104.9 & 20.0 & 50.0 & 1.48 & 0.60 & 0.66 \\
\hline $\mathbf{T}_{\mathbf{3}}$ & $\begin{array}{l}\text { Quizalofop-ethyl } 5 \% \text { EC } 50 \mathrm{~g} \text { a.i./ha PoE } \\
f b \text { IC + HW at } 30 \text { DAS }\end{array}$ & 4.96 & 9.29 & 26.39 & 103.9 & 18.6 & 49.0 & 1.68 & 0.55 & 0.73 \\
\hline $\mathbf{T}_{4}$ & $\begin{array}{l}\text { Imazamox } 35 \% \text { + imazethapyr } 35 \% \text { (Pre- } \\
\text { mix) WG } 70 \mathrm{~g} \text { a.i./ha PoE }\end{array}$ & 4.62 & 8.75 & 26.69 & 98.8 & 17.1 & 49.1 & 1.40 & 0.58 & 0.65 \\
\hline $\mathbf{T}_{\mathbf{5}}$ & $\begin{array}{l}\text { Propaquizafop } 10 \% \text { EC } 75 \mathrm{~g} \text { a.i./ha PoE } f b \\
\text { IC + HW at } 30 \text { DAS }\end{array}$ & 5.08 & 9.45 & 26.92 & 109.8 & 19.0 & 49.0 & 1.58 & 0.56 & 0.69 \\
\hline $\mathbf{T}_{6}$ & $\begin{array}{l}\text { Fenoxaprop-p-ethyl } 9 \% \text { EC } 67.5 \mathrm{~g} \text { a.i./ha } \\
\text { PoE } f b \text { IC + HW at } 30 \text { DAS }\end{array}$ & 4.77 & 8.97 & 25.98 & 107.5 & 18.0 & 48.1 & 1.46 & 0.56 & 0.72 \\
\hline $\mathbf{T}_{7}$ & FP (IC $f b \mathrm{HW}$ at $20 \& 40 \mathrm{DAS})$ & 4.90 & 9.28 & 25.47 & 100.6 & 18.3 & 44.7 & 1.58 & 0.53 & 0.68 \\
\hline \multirow[t]{5}{*}{$\mathbf{T}_{8}$} & Weedy check & 4.73 & 8.93 & 24.67 & 100.2 & 17.9 & 46.6 & 1.52 & 0.55 & 0.61 \\
\hline & S. Em. \pm & 0.11 & 0.16 & 0.71 & 2.93 & 0.60 & 1.28 & 0.06 & 0.02 & 0.02 \\
\hline & F - test & NS & NS & NS & NS & NS & NS & NS & NS & NS \\
\hline & $\mathbf{Y} \times \mathbf{T}$ & $\begin{array}{l}0.19 \\
\text { NS }\end{array}$ & $\begin{array}{l}0.28 \\
\text { NS }\end{array}$ & $\begin{array}{l}1.24 \\
\mathrm{NS}\end{array}$ & $\begin{array}{l}5.1 \\
\mathrm{NS}\end{array}$ & $\begin{array}{l}1.04 \\
\text { NS }\end{array}$ & $\begin{array}{l}2.2 \\
\mathbf{N S}\end{array}$ & $\begin{array}{l}0.11 \\
\text { NS }\end{array}$ & $\begin{array}{l}0.04 \\
\mathrm{NS}\end{array}$ & $\begin{array}{c}\text { 0.04 } \\
\text { NS }\end{array}$ \\
\hline & CV \% & 7.9 & 6.2 & 9.5 & 9.52 & 11.3 & 9.2 & 14.8 & 14.04 & 14.31 \\
\hline
\end{tabular}


From the above result it can be concluded that post-emergence (20 - 25 DAS) application of propaquizafop $10 \% \mathrm{EC} 75 \mathrm{~g}$ a.i./ha $f b \mathrm{IC}+$ $\mathrm{HW}$ at 30 DAS or quizalofop-ethyl $5 \% \mathrm{EC}$ $50 \mathrm{~g}$ a.i./ha $f b \mathrm{IC}+\mathrm{HW}$ at $30 \mathrm{DAS}$ or fenoxaprop-p-ethyl 9\% EC $67.5 \mathrm{~g}$ a.i./ha $f b$ $\mathrm{IC}+\mathrm{HW}$ at $30 \mathrm{DAS}$ provide effective control of weeds and also enhance the number of branches/plant, number of pods/plant, number of seeds/pod, seed yield, haulm yield, net return and BCR of blackgram and there was no any residual effect of herbicides on succeeding crops viz., maize, gram and wheat.

\section{Acknowledgement}

The authors are thankful to Director of Research and Dean Post Graduate Studies, Anand Agricultural University, Anand for providing all the necessary facilities and encouragement during present investigation

\section{References}

Anonymous. Ministry of Agriculture \& Farmers' Welfare, Govt. of India (ON1953): 2017-18.

Balyan, J.K., Choudhary, R.S., Kumpawat, B.S. and Choudhary, R. 2016. Weed management in blackgram under rainfed conditions. Indian Journal of Weed Science, 48(2): 173-177.

Chand, R., Singh, N.P. and Singh, V.K. 2004. Effect of weed control treatments on weeds and grain yield of late sown urdbean (Vigna mungo L.) during Kharif season. Indian Journal of Weed Science, 36: 127-128.
Gogoi, A.K., Kalita, H., Pathal, A.K., and Deka, J. 1992. Crop-weed competition in rainfed blackgram. Indian Journal of Weed Science, 24: 81-83.

Jana, P.K., Mallick. S., Barman, S.K., Bera, S. and Ghosh, R.K. Studies on bioefficacy and phytotoxicity of propaquizafop 10 EC on weed management of onion and its follow up blackgram. Production \& management of spices in west bengal- a state level seminar: 1-2 ${ }^{\text {nd }}$ March, 2012.

Maity, S.K. and Mukherjee, P.K. 2011. Effect of brown manuring on grain yield and nutrient use efficiency in dry direct seeded Kharif rice. Indian Journal Weed Science, 43(1\&2): 61-66.

Mundra, S.L. and Maliwal, P.L. 2012. Influence of quizalofop-ethyl on narrow- leaved weeds in blackgram and its residual effect on succeeding crops. Indian Journal of Weed Science, 44(4): 231-234.

Rathi, J.P.S., Tewari, A.N. and Kumar, M. 2004. Integrated weed management in blackgram (Vigna mungo L.). Indian Journal of Weed Science, 36: 218-220.

Sarswat, V.N. and Mishra, J.S. 1993. Weed management in pulse crops. In: Proceedings of International Symposium of Indian Society of Weed Science, CCS HAU, Hisar, $18^{\text {th }}-20^{\text {th }}$ November, 11: 37-140.

Yadav, R. and Bhullar, M.S. 2014. Residual effect of soybean herbicides on the succeeding winter crops. Indian Journal of Weed Science, 46(3): 305-307.

\section{How to cite this article:}

Machhar, R. G., R. V. Hajari, A. K. Mahida, G. D. Hadiya and Damor, C. B. 2020. Impact of Herbicides on Yield Attributes and Yields of Blackgram (Vigna mungo L.) and their Residual Effects on Succeeding Crops. Int.J.Curr.Microbiol.App.Sci. 9(06): 3380-3386. doi: https://doi.org/10.20546/ijcmas.2020.906.400 